Goldschmidt 2021 Abstract

https://doi.org/10.7185/gold2021.6603

\section{Particulate excess Ba as a proxy for biological productivity along the North Atlantic and South Pacific GEOTRACES transects}

\author{
SHAILY RAHMAN ${ }^{1}$, ALAN SHILLER ${ }^{2}$, ROBERT \\ ANDERSON $^{3}$, CHRISTOPHER T HAYES $^{2}$, PHOEBE J. \\ LAM $^{4}$, DANIEL OHNEMUS ${ }^{5}$, FRANK PAVIA ${ }^{6}$, BENJAMIN \\ TWINING $^{7}$ AND SEBASTIAN VIVANCOS ${ }^{3}$ \\ ${ }^{1}$ University of Southern Mississippi, University of Colorado \\ Boulder \\ ${ }^{2}$ University of Southern Mississippi \\ ${ }^{3}$ Columbia University \\ ${ }^{4}$ University of California, Santa Cruz \\ ${ }^{5}$ UGA Skidaway Institute of Oceanography \\ ${ }^{6}$ California Institute of Technology \\ ${ }^{7}$ Bigelow Laboratory for Ocean Sciences \\ Presenting Author: shaily.rahman@usm.edu
}

Through the formation of particulate organic carbon (POC), marine primary production consumes $>50 \%$ of atmospheric $\mathrm{CO}_{2}$ and plays a major role in controlling atmospheric $\mathrm{CO}_{2}$ over glacial/interglacial timescales. Of the $\sim 4200 \mathrm{Tmol} / \mathrm{y}$ of POC that is produced in the surface ocean, $<1 \%$ arrives to the seafloor, much of it being respired in the mesopelagic zone $(100-1000 \mathrm{~m})$. Particulate excess barite $\left(\mathrm{pBa}_{\mathrm{xs}}\right)$ is thought to form in the water column within decaying organic matter and has preservation efficiencies higher than POC. Using $\mathrm{pBa}_{\mathrm{xs}}$ concentrations and ${ }^{230} \mathrm{Th}$-normalized fluxes in the water column and sediment, the accuracy of $\mathrm{pBa}_{\mathrm{xs}}$ as a productivity proxy was tested along the US GEOTRACES GA03 North Atlantic (NAZT) and GP16 Eastern Tropical Pacific (EPZT) transects, which traversed both near-shore and open-ocean gyre stations. Depth weighted averages of $\mathrm{pBa}_{\mathrm{xs}}$ were determined for two mesopelagic depth intervals and compared to the attenuation of ${ }^{230} \mathrm{Th}$-normalized POC flux estimates. Averages were typically higher in the EPZT $(\sim 230-410 \mathrm{pM} / \mathrm{l})$ than the NAZT $(\sim 100-330 \mathrm{pM} / \mathrm{l})$, and corresponded with respiration estimates derived from POC flux. For example, in $100-500 \mathrm{~m}$ of the EPZT water column, $\mathrm{pBa}_{\mathrm{xs}}{ }^{-}$ based POC respiration rates ranged from $0.6-5.7 \mathrm{mmol}-\mathrm{C} / \mathrm{m}^{2} / \mathrm{d}$, whereas rates based on POC attenuation were 1.2-6.2 mmol$\mathrm{C} / \mathrm{m}^{2} / \mathrm{d}$.

Available $\mathrm{pBa}_{\mathrm{xs}}$ mass accumulation rates (MAR) at EPZT stations were used to calculate export production in the water column using two well-known algorithms [1, 2]. Export production (EP) was also calculated by applying Martin (powerlaw fit) and $1^{\text {st }}$-order kinetic (exponential fit) models to ${ }^{230} \mathrm{Th}$ normalized POC flux curves using several estimates of euphotic zone depth (e.g., deep chlorophyll maximum or particle production zone). Sedimentary $\mathrm{pBa}_{\mathrm{xs}}$-based EP estimates were poorly correlated $\left(r^{2} \sim 0.0-0.4\right)$ to EP estimates based on water column POC flux. Correlations in gyre stations were often negative. However, excess barite appears to be a reasonable proxy for POC respiration in the water column. We suggest that $\mathrm{pBa}_{\mathrm{xs}}$ MARs at stations underlying the EPZT are not a good proxy for EP due to sediment movement or benthic dissolution of $\mathrm{pBa}_{\mathrm{xs}}$ post-deposition.

[1] Dymond et al. (1992) Paleoceanography 7, 163-181. [2] Francois et al. (1995) GBC 9, 289-303. 